\title{
Upaya Birokrasi Pemerintah dalam Mensosialisasikan Covid-19 di Lingkungan Masyarakat
}

\author{
Nurliza Fatimah ${ }^{1}$, Lala Amelinda $\mathrm{F}^{2}$, Trinadi Maulana $\mathrm{P}^{3}$ \\ 1,2,3 Universitas Muhammadiyah Malang, Malang, Indonesia \\ 1 nurlizafatimah@gmail.com; ${ }^{2}$ lalaamelinda99@gmail.com; ${ }^{3}$ trinadi300399@ gmail.com \\ * corresponding author
}

\section{ARTICLE INFO}

\section{Article history}

Received 2020-04-29

Revised 2020-05-11

Accepted 2020-06-28

Keywords

Collaboration; Pentahelix; Local wisdom.

\begin{abstract}
In December 2019, the world was shocked by the presence of a new virus in Wuhan, one of the cities in China, the Corona Virus or commonly referred to as Covid-19. Covid-19 is a contagious disease and therefore prevention of Covid-19 should be done as soon as possible. The Chinese National Health Commission explains that the coronavirus is easy to spread, Covid-19 can be transmitted from humans to humans who have been infected with Covid-19. Besides Covid-19 can also be attached to items that have been touched by patients who are positive for Covid-19 and are close to Covid-19 patients. The existence of Covid-19 caused panic everywhere - one of them in Indonesia, in dealing with Covid-19, the Indonesian government has provided new policies and appeals to the community to overcome the Covid-19 outbreak. But there are still many people who do not obey the appeal of the government and violate the policies that have been made by the Government. Therefore this study aims to analyze how the efforts of the government bureaucracy in socializing Covid-19 in the community environment. The method used in this study is the method of literature to produce data in the form of descriptive data, words or words from individuals who are observed, then observed, the object of research in the form of the library works in the form of scientific journals, books, mass media articles.
\end{abstract}

\section{PENDAHULUAN}

Indonesia merupakan suatu negara yang memiliki jumlah penduduk terpadat di dunia, dimana penduduknya mempunyai macam-macam ciri khas dari budaya, suku, adat istiadat, dan Agama. Dengan adanya keanekaragaman ciri khas ini Indonesia telah menganut paham sistem konsepsi negara hukum yang dimaksud dengan memberikan sesuatu hal mengenai peran penting kepentingan umum serta pentingnya kesejahteraan masyarakatnya. Menganut Falsafah Pancasila sebagai negara hukum, dengan tujuan untuk mencapai pembangunan nasional dalam menciptakan keadilan sosial pada masyarakat serta kesejahteraan bagi lingkungan dan masyarakat yang sesuai pada pembukaan Undang-undnag Dasar 1945 Alinea ke - 4. Sehingga dengan adanya pemahaman mengenai masyarakat Indonesia yang tercantum pada undang-undang 1945 dapat membuka peluang pemikiran pemerintah dan masyarakatnya untuk menjalankan sistem tersebut sesuai aturan yang telah dibuat dan di tetapkan secara paten.

Menurut Weber birokrasi adalah suatu metode organisasi terbaik dengan adanya bentuk spesialisasi tugas. Dalam bukunya yang berjudul Eassy in Sociology, bahwa kekuasaan adalah kesempatan seseorang untuk menyadarkan masyarakat akan kemauannya sendiri (Fatkhuri 2018). Sekaligus menerapkan terhadap tindakan perlawanan dari orang-orang ataupun golongan tertentu. akan tetapi, yang di maksud oleh Weber sendiri untuk di terapkan pada fungsi birokrasi pemerintahan Indonesia hendaknya di filter terlebih dahulu dalam tatanan bentuk peran serta tujuan yang akan di capai. oleh sebab itu tugas birokrasi merupakan alat pelaksana jalannya pemerintahan dalam merealisasikan sosialisasi untuk kesejahteraan masyarakat. Dengan tujuan untuk mengatur kehidupan maupun menata pembangunan serta berfungsi sebagai kontrak sosial masyarkat indonesia dalam menciptakan tatanan negara yang menuju keadilan dan kemakmuran agar berjalan dengan tertib dan teratur serta diusahakan 
sedemikan rupa. Sehingga tujuan yang telah dicapai dapat dirasakan secara proposional dan setiap individu dapat memenuhi kebutuhan hidupnya secara teratur. Demikian nantinya, segala bentuk aspek keadilan, ketertiban dan kesejahteraan masyarakat termasuk tujuan pokok utama dalam peranan penting untuk birokrasi pemerintahan. Keadilan sendiri memiliki keterkaitan pada kemakmuran, dimana pengertian adil dikaitkan dalam lingkup kehidupan bersama yang bertujuan pemenuhan hak dan kewajiban baik dalam bidang hukum maupun moral, sedangkan pengertian makmur merupakan bentuk tercapainya pemenuhan kebutuhan hidup. Sehingga perpaduan antara adil dan makmur merupakan landasan hidup yang direalisasikan melalui pembangunan nasional yang terpadu dan menyeluruh. Mengenai keterkaitan dengan birokrasi yang efektif demi terwujudnya pelayanan publik yang adil dan makmur.

Intinya untuk melakukan pelaksanaan tersebut birokrasi harus mampu melayani masyarakat sesuai dengan Undang-Undang Pelayanan Publik Nomor 25 Tahun 2009, Dimana dalam ketentuan pada pasal 4 telah disebutkan, sebagai berikut : Pertama, terwujudnya batasan dan hubungan secara jelas tentang hak, tanggung jawab, kewajiban, dan kewenangan pada seluruh pihak yang terkait dengan penyelenggaraan pelayanan publik. Kedua, terwujudnya sistem penyelenggaraan pelayanan publik secara layak sesuai dengan asas-asas umum pemerintahan dan korporasi yang baik. Ketiga, terpenuhinya penyelenggaraan pelayanan publik sesuai dengan peraturan perundang-undangan yang telah ada. Keempat, terwujudnya perlindungan dan kepastian hukum bagi masyarakat dalam penyelenggaraan pelayanan publik(Budiman 2017). Dengan demikian, Sebagai pelaksana birokrasi harus mampu memberikan kinerja yang sangat efektif terhadap berlangsungnya roda pemerintahan. Tata kelola pemerintahan sangat di perlukan untuk sistem birokrasi yang mengutamakan keadilan dan kemakmuran rakyatnya. Serta untuk mengetahui segala berbagai adanya keluh kesah yang di rasakan oleh masyarakat. Oleh sebab itu peran penting Birokrasi ini merupakan sistem terpenting untuk mewujudkan kesejahteraan masyarakat. Dalam Pelaksana birokrasi harus mampu memberikan solusi dan jalan keluar dalam memecahkan sebuah masalah yang sedang di hadapi di lingkungan masyarakat. Sehingga, masyarakat mampu merasakan bentuk sebuah perkembangan dan perubahan secara signifikan dengan adanya pelayanan publik yang diberikan pemerintah sebagai pelaksana birokrasi.

Jadi bentuk peranan penting Birokrasi Pemerintahan adalah bagaimana cara memberikan bantuan dan kemudahan kepada masyarakat dalam rangka memenuhi kebutuhan dan kepentingannya. Dan dibutuhkannya sikap tolong menolong, bersahabat, dan profesional dalam memberikan pelayanan jasa dari suatu instansi yang dapat memuaskan masyarakat kedepannya.

\section{TUJUAN PENELITIAN}

Tujuan Penelitian ini adalah untuk mengetahui upaya Birokrasi dalam mensosialisasikan covid-19 ini di lingkungan Masyarakat secara optimal. Manfaat Penelitian ini adalah untuk mengetahui bagaimana birokrasi pemerintahan dalam mensosialisasikan mengenai covid-19 di lingkungan masyarakat dan untuk memberikan panduan mengenai penanganan wabah ini pada masyarakat agar dilakukan secara baik dan benar. Masukan tersebut diharapkan dapat meningkatkan partisipasi pemerintah dan masyarakat dalam menghadapi wabah ini, sehingga negara kita dapat berhasil menangani wabah ini tanpa adanya penambahan korban akibat covid-19.

\section{TINJAUAN PUSTAKA}

Sebagai tolak ukur untuk berpikir ataupun bertindak maka teori yang dibutuhkan adalah teori berpikir secara ilmiah, karena teori merupakan bentuk kebenaran yang sudah dibuktikan kebenarannya secara faktual dalam kaitan suatu permasalahan.

\section{Birokrasi dan Kebijakan Publik}

Birokrasi dan Kebijakan Publik antara keduanya tidak dapat dipisahkan. Karena Kebijakan publik tidak dapat lahir secara instan tanpada adanya campur tangan dari Birokrasi, demikian sebaliknya kebijakan publik sendiri tidak dapat diimplementasikan tanpa mengikutsertakan ke aktifan birokrasi. Di dalam Birokrasi terdapat pihak-pihak yang terlibat serta mengelilingi, mempengaruhi aktivitasnya sehingga dapat mempengaruhi kebijakan yang telah dihasilkannya(Sumaryana 2005). Dalam kajian administrasi negara sendiri didalamnya berkumpul birokrasi dengan bertugas menjalankan kebijakan 
publik yang tidak dapat mengabaikan lingkungan sebagai pihak yang tidak memiliki kontribusi apapun terhadap pelaksanaan pelayanan publik. Sehingga, kebijakan publik sendiri tercermin dari pelaksanaan tugas birokrasi dalam melaksanakan pelayanan publik sehingga baik buruknya pelayanan kepada publik akan mencerminkan kualitas bentuk birokrasi. Oleh sebab itu, Birokrasi menghasilkan bentuk Kebijakan publik yang berguna memberikan bentuk pelayanan terbaik kepada masyarakat.

Thoha (1999, p. 58) mengutarakan bahwa kebijakan (policy) disatu sisi dapat berbentuk suatu usaha yang komplek dari masyarakat untuk kepentingan masyarakat, di lain pihak policy merupakan suatu bentuk teknik atau cara untuk mengatasi konflik dan insentif(Hendri 2018). Selain itu Lasswell dan Kaplan yang dikutip Thoha (1999, p. 71) memberikan beberapa definisi tentang kebijakan sebagai sesuatu program pencapaian tujuan, nilai-nilai dalam praktek-praktek yang terarah (a projected profram of goal, value and practices). Menurut Anderson yang dikutip Winarno (2002, p. 16), kebijakan merupakan suatu arah tindakan yang mempunyai maksud dengan ditetapkan oleh seorang aktor atau sejumlah aktor dalam mengatasi suatu masalah dan persoalan. Kebijakan yang dikeluarkan oleh pemerintah pada umumnya dikenal sebagai kebijakan publik. Dye (1981, p. 3) menyatakan bahwa kebijakan publik menyangkut "whatever government chooses to do or not to do". Hal tersebut mengartikan bahwa kebijakan publik merupakan pilihan apapun oleh pemerintah, baik untuk melaksanakan sesuatu maupun untuk tidak melaksanakan sesuatu. Sehingga, pengertian ini menyamakan kebijakan pemerintah dengan bentuk tindakan-tindakan pemerintah, dan memandang setiap pilihan tindakan yang dilakukan oleh pemerintah sudah tentu memiliki tujuan dan sasaran yang akan di capai.

\section{Sosialisasi}

Sosialisasi dapat diartikan sebagai bentuk upaya dalam memasyarakatkan sesuatu sehingga menjadi dikenal merupakan pengertian yang paling dapat diterima dalam kontek kajian kebijakan publik dibandingkan Kebijakan dalam mensosialisasikan suatu masalah perlu diketahui oleh masyarakat sehingga kebijakan tersebut selain dapat terlaksana dengan baik juga mendapat dukungan dari masyarakat. Kemudian dilihat dari bentuk substansinya kajian kebijakan publik dimana proses masyarakat dalam memahami suatu kebijakan hingga akhirnya mematuhi atau turut terlibat dalam melaksanakan kebijakan tersebut merupakan domain kajian kebijakan publik. Akan tetapi, pengertian ini juga tidak sepenuhnya tepat, dikarenakan "memasyarakatkan" kebijakan konteks kajian kebijakan publik memiliki kekhususan hanya untuk kelompok masyarakat sasaran sebagaimana yang telah diatur dalam isi atau substansi kebijakan dan tidak mencakup semua warga masyarakat secara luas. Menurut Zanden (1979) juga menyatakan bahwa, Sosialisasi merupakan bentuk proses interaksi sosial yang mana seorang individu mengenal cara berfikir, berperasaan dan bertingkah laku yang akan membuatnya berperan dalam suatu lingkungan masyakat(D. Herdiana 2018). Maksudnya, sosialisasi merupakan proses yang dilakukan setelah suatu kebijakan dibuat dan dilakukan dimana kebijakan memasuki tahap implementasi. Dalam hal ini, sosialisasi memiliki kedudukan secara strategis dalam terlaksananya implementasi kebijakan secara benar untuk tujuan kebijakan yang telah dibuat dalam proses formulasi kebijakan. Oleh sebab itu, penyebarluasan informasi mengenai isi atau substansi kebijakan yang telah dibuat tersebut merupakan penjabaran isi atau substansi dari suatu kebijakan yang telah dibuat. Adanya bentuk Kejelasan informasi dalam proses sosialisasi akan menentukan tingkat pengetahuan dan pemahaman dari pihak-pihak yang akan terlibat dalam implementasi suatu kebijakan yang telah dibuat, sehingga isi atau substansi kebijakan tersebut harus benar-benar jelas, rinci dan dapat dipahami dengan mudah.

Lain halnya menurut, James. W. Vander Zanden ia memberikan pendapat bahwa, Sosialisasi ialah proses interaksi sosial dimana orang memperoleh pengetahuan, nilai, sikap dan perilaku esensial untuk berpartisipasi secara efektif dalam masyarakat. Yang berarti, bahwa sosialisasi merupakan suatu proses transmisi pengetahuan, sikap, nilai, norma, dan perilaku esensial yang bertujuan agar mampu berpartisipasi secara efektif dalam masyarakat(Adetia Reza Ariska, Apri Diansyah, Erlina Lestari, Ratna M 2014).

\section{METODE PENELITIAN}

Untuk memenuhi kebutuhan penelitian, metodologi dalam penelitian ini menggunakan metode kepustakaan untuk menghasilkan data berupa data deskriptif kata-kata atau ucapan dari individu yang diamati, kemudian di observasi, yang objek penelitiannya berupa karya-karya kepustakaan baik berupa 
jurnal ilmiah, buku, artikel media massa. Kepustakaan tersebut akan di digunakan untuk menjawab permasalahan penelitian yang ditunjukan oleh penulis untuk menunjukan upaya birokrasi pemerintahan dalam mensosialisasikan Covid-19 dilingkungan masyarakat.

\section{HASIL DAN PEMBAHASAN}

\section{Sosialisasi dalam Perspektif Kebijakan Publik}

Sosialisasi dalam Kamus Besar Bahasa Indonesia (KBBI) memiliki 3 (tiga) arti Pertama, suatu usaha untuk mengubah milik seseorang atau perseorangan menjadi milik umum atau milik negara. Kedua, proses belajar seorang anggota masyarakat untuk mengenal dan menghayati kebudayaan masyarakat dalam lingkungannya. Ketiga, upaya memasyarakatkan sesuatu sehingga menjadi dikenal (KBBI, 2016). Sosialisasi kebijakan publik dapat diartikan sebagai: "upaya penyebarluasan isi atau substansi suatu kebijakan yang telah dibuat dengan maksud untuk memunculkan pengetahuan dan pemahaman dari berbagai pihak yang terkait, termasuk didalamnya kelompok sasaran (target group) agar mau dan mampu menjalankan perannya dalam menyukseskan tujuan sebagaimana tercantum dalam kebijakan tersebut". Dari pemahaman tersebut maka dapat dijelaskan pengertian sosialisasi dalam konteks kebijakan publik memiliki unsurunsur sebagai berikut:

Pertama, sosialisasi merupakan kegiatan yang dilakukan oleh pihak yang diberi kewenangan sebagaimana diatur dalam suatu kebijakan, aktor tersebut pada umumnya merupakan aparat pemerintah yang secara legal-formal memiliki kewenangan dan terikat dengan kebijakan yang telah dibuat tersebut, apakah itu pihak yang terlibat langsung dalam proses perumusan kebijakan (dalam tahap formulasi kebijakan), atau pihak yang sengaja ditunjuk oleh pemerintah untuk melakukan kegiatan sosialisasi, atau juga pihak yang akan terlibat langsung dalam implementasi kebijakan tersebut, sehingga pihak-pihak tersebut harus memastikan bahwa pihak lainnya beserta kelompok sasaran mengetahui isi atau substansi dari suatu kebijakan yang telah dibuat tersebut. Kedua, adanya penyebarluasan informasi yang dilakukan mengenai isi atau substansi kebijakan yang telah dibuat tersebut yang mana hal ini merupakan penjabaran isi atau substansi dari suatu kebijakan yang telah dibuat. Kejelasan akan adanya informasi dalam proses sosialisasi akan menentukan tingkat pengetahuan dan pemahaman dari pihak-pihak yang akan terlibat dalam implementasi suatu kebijakan yang telah dibuat, sehingga isi atau substansi kebijakan tersebut harus benar-benar jelas, rinci dan dapat dipahami dengan mudah. Ketiga, adanya kelompok sasaran atau dalam istilah lainnya disebut target group yang mana kelompok tersebut merupakan objek yang akan dikenakan suatu kebijakan. Kelompok sasaran menjadi penentu apakah kebijakan yang telah dibuat akan berhasil atau tidak, hal ini dikarenakan maksud dari suatu kebijakan yang dibuat tersebut yaitu untuk merespons atau menanggulangi permasalahan yang ada dalam kelompok sasaran tersebut. Keempat, adanya tujuan untuk memberikan pengetahuan dan pemahaman mengenai isi atau substansi kebijakan yang telah dibuat, hal ini merupakan inti dari kegiatan sosialisasi kebijakan publik yang mana pihak-pihak yang akan terlibat dapat mengetahui dan memahami suatu kebijakan yang telah dibuat tersebut. Dengan adanya pengetahuan dan pemahaman, maka pihak-pihak tersebut dapat memahami kedudukan dan perannya masing-masing yang diharapkan dapat secara optimal terlibat dan berkontribusi dalam pelaksanaan suatu kebijakan yang telah dibuat. Kelima, adanya respons yang diharapkan yaitu berupa keterlibatan berbagai pihak yang terkait dalam tahap implementasi kebijakan. Dengan telah dilakukannya sosialisasi yang memberikan pengetahuan dan pemahaman kepada pihak-pihak yang terkait, maka berbagai pihak tersebut akan memiliki sikap dan tindakan berupa kesadaran dan rasa tanggungjawab untuk menyukseskan implementasi kebijakan yang telah dibuat sesuai dengan perannya masing-masing(D. Herdiana 2018).

\section{Upaya Pemerintah dalam Mensosialisasikan Covid-19 di Lingkungan Masyarakat}

Sosialisasi secara sederhana dipahami sebagai proses internalisasi nilai dan orma sosial ke dalam individu. Sosialisasi merupakan bagian inti dari proses interaksi sosial. Sebagai makhluk sosial, kita senantiasa berinteraksi dengan manusia lainnya. Dalam proses interaksi, terjadi sosialisasi. Proses sosialisasilah yang membuat seseorang menjadi tahu bagaimana seharusnya seseorang bertingkah laku di tengah-tengah masyarakat dan lingkungannya. Proses sosialisasi membawa seseorang dari keadaan belum tersosialisasi menjadi masyarakat dan beradab. Melalui sosialisasi, seseorang secara berangsur- 
angsur mengenal persyaratan-persyaratan, tuntutan- tuntutan dan kebijakan-kebijakan yang telah di sepakati bersama.

Makna dari sosialisasi merupakan proses hasil belajar dari pengalaman yang ada, Memberikan indikasi umum hasil belajar tingkah laku individu dan kelompok dalam batas-batas yang luas dan lebih khusus berkenaan dengan pengetahuan atau informasi, nilai dan sikap, Sosialisasi tidak dibatasi usia,Sosialisasi merupakan prakondisi yang diperlukan bagi aktivitas social, Sosialisasi politik dapat dilakukan di berbagai lingkungan, seperti di lingkungan keluarga, lingkungan sekolah, lingkungan kehidupan bernegara.Lewat proses sosialisasi juga, seseorang bisa belajar tentang semua hal yang berkaitan dengan kepentingan pribadinya ataupun kepentingan orang lain. Dengan begitu, mendapatkan ilmu yang luas yang berkaitan dengan masalah-masalah yang ada di dalam masyarakat akan lebih mudah. Lalu sebenarnya apa tujuan dari sosialisasi yang tengah dilakukan pemerintah untuk mencegah atau memutuskan penyebaran covid-19? Berikut tujuan sosialisasi.Tujuan dari sosialisasi politik untuk memperluas pemahaman dan penghayatan serta wawasan terhadap masalah-masalah yang berkembang, dapat meningkatkan kualitas kesadaran masyarakat mengenai fenomena atau suatu pemasalahan dalam Pencegahan dan pengendalian COVID-19 harus ditempatkan pada prioritas yang paling utama dalam segala kebijakan pemerintahan. Institusi kesehatan pada semua tingkatan/ level harus mengikuti petunjuk pemerintah pusat/ daerah setempat dan memperkuat pedoman kerja pencegahan dan pengendalian epidemi local dan membentuk kelompok ahli pencegahan dan pengendalian COVID-19 yang melibatkan para ahli dan pemangku kepentingan terkait. Pemerintah Indonesia saat ini sudah melakukan upaya untuk memutus mata rantai penularan virus Corona. Imbauan itu menjaga jarak fisik (physical distancing), kerja dari rumah, belajar di rumah, hingga beribadah di rumah terus digaungkan sehingga(Yunus and Rezki 2020). Hal itu terkait sifat virus Corona yang menular antarmanusia. Penularan bisa terjadi melalui percikan.Itulah mengapa diharapkan warga menjaga jarak fisik dengan sesamanya untuk meminimalisasi risiko terkena percikan (droplet), atau menyentuh benda yang sebelumnya terkena droplet.

Dalam mensosialisasikan mengenai covid-19 pemerintah mempunyai strategi untuk masyarakat dalam penjelasan mengenai pandemic yang mewabah saat ini, yaitu dengan cara memberikan penjelasan menggunakan bahasa daerah masing-masing yang diharapkan masyarakat bisa memahami dengan benar apa yang telah disampaikan oleh pemerintah(Kementrian Dalam Negri 2013). pemerintah dalam hal ini mengikut sertakan bebrapa influens (artis,seniman,selebritis,selebgram) untuk mensosialisakan mengenai pandemi untuk tetap berada di rumah, memberikan edukasi supaya pemutusan virus ini lebih cepat terselesaikan. Selain itu pemerintah telah merilis situs covid19.go.id untuk memberikan edukasi kepada masyarakat terkait virus Corona terbaru. Pemerintah memberikan informasi mengenai tiga langkah penting untuk mencegah terjangkit virus corona, termasuk cara mengurangi risiko serta apa yang perlu dilakukan saat sakit. Tiga langkah pencegahan COVID-19 yang dianjurkan pemerintah.

\section{Ketahui Cara Mengurangi Risiko}

Untuk mencegah penularan, cara yang sebaiknya dilakukan adalah dengan mengetahui risiko dan menghindarinya termasuk dengan menjaga kebersihan. Namun, pemerintah juga menyarankan bagi masyarakat untuk melakukan social distancing atau mengurangi kontak langsung dengan orang lain.

\section{Ketahui Informasi yang Benar}

Masyarakat harus tetap mengikuti perkembangan informasi tentang virus COVID-19 ini. Negaranegara dengan banyak kasus virus Corona telah mengeluarkan regulasi-regulasi baru untuk menghentikan penyebaran. Di sisi lain, masyarakat diharapkan untuk dapat membedakan informasi yang salah atau berita hoaks yang beredar. Pasalnya, kemudahan melakukan komunikasi yang didukung dengan perangkat digital justru sering disalahgunakan dengan banyaknya penyebaran informasi yang salah. Ikuti selalu informasi terbaru dari sumber-sumber yang dapat dipercaya. 
3. Ketahui Apa yang Perlu Dilakukan Saat Sakit

Jika mengalami sakit dapat melakukan pemeriksaan menuju rumah sakit terdekat untuk memastikan kesehatan terlebih bila keluhan berlanjut, atau disertai dengan kesulitan bernapas. Pada saat berobat ke fasilitas layanan kesehatan sebaiknya gunakan masker. Apabila tidak memiliki masker, ikuti etika batuk atau bersin yang benar dengan menutup mulut dan hidung dengan siku terlipat atau tisu yang langsung dibuang ke tempat sampah tertutup. Tenaga kesehatan di fasilitas pelayanan kesehatan akan melakukan screening suspect. Jika memenuhi kriteria suspek virus corona (COVID-19), Anda akan dirujuk ke salah satu rumah sakit rujukan yang siap menanganani COVID-19. Namun, jika tidak memenuhi kriteria suspek, Anda akan dirawat inap atau rawat jalan tergantung diagnosa dan keputusan dokter. Sementara, segera hubungi Hotline Center Corona 119 ext 9 apabila Anda dalam keadaan sehat namun melakukan perjalanan pada kota atau negara terjangkit COVID-19 dalam 14 hari terakhir.

Selain itu, dalam menangani penanggulangan Covid-19 Pemerintah dan Dinas Kesehatan (DINKES) juga memberikan bentuk himbauan kepada masyarakat untuk terus menjaga jarak aman dan tidak berkumpul ditengah keramaian (melakukan social distancing). Pemerintah dan dinas kesehatan telah membuat protokol isolasi diri sendiri tanpa perlu keluar rumah dan beberapa langkah upaya dalam menangani Covid-19. Sehingga, masyarakat dapat mengantisipasi dalam menjaga kesehatan serta menjaga diri dari serangan wabah ini. Berikut Protokol isolasi diri yang telah dikeluarkan oleh DINKES

1. Jika sakit tetap di rumah

Hal ini dikarenakan jika sedang dalam kondisi tidak fit, tentu imun tubuh akan menurun. Jadi diusahakan untuk tidak keluar rumah dan pergi ke tempat keramaian. Tindakan ini bisa menjadi salah satu cara untuk menghindari penyebaran virus corona.

2. Isolasi diri sendiri

Dengan mengisolasi dan memantau diri sendiri, dapat membantu banyak orang untuk menghindari kemungkinan penularan kepada orang-orang disekitar termasuk keluarga.

3. Yang dilakukan saat isolasi diri

Tanpa perlu ke rumah sakit, yang bisa di lakukan saat isolasi diri sendiri adalah:

a) Tinggal di rumah

b) Gunakan kamar terpisah dari orang lain

c) Gunakan masker selama masa isolasi

d) Terapkan perilaku hidup bersih dan sehat

4. Orang Dalam Pemantauan

Meski tidak memiliki gejala yang menunjukkan virus corona, tetapi pernah melakukan kontak erat dengan pasien positif virus corona, maka termasuk dalam ODP dan perlu melakukan isolasi diri sendiri untuk menghindari penyebaran kepada banyak orang.

5. Yang dilakukan saat pemantauan diri sendiri

a) Lakukan observasi/pemantauan diri sendiri di rumah

b) Lakukan pengukuran suhu harian dan observasi gejala klinis seperti batuk atau kesulitan bernapas

c) Jika ada gejala, laporkan pada petugas di fasilitas layanan kesehatan terdekat

d) Jika hasil sampel dan pemeriksaan dinyatakan positif, maka segera lakukan isolasi diri dengan menjauhkan diri dari orang sekitar termasuk keluarga

6. Tindakan Pencegahan

Selain menjaga jarak sosial, dapat melakukan beberapa cara berikut untuk tindakan pencegahan:

a) Cuci tangan pakai sabun dan air mengalir

b) Tutup mulut dan hidung saat batuk ataupun bersin

c) Jaga jarak sosial setidaknya 1 meter dengan orang lain

d) Hindari menyentuh mata, hidung, dan mulut sebelum mencuci tangan 
7. Saat perlu memakai masker

Banyak orang merasa khawatir dan memburu masker untuk mencegah penularan virus. Padahal sebenarnya masker perlu digunakan oleh orang-orang berikut ini:

a) Orang dengan gejala pernapasan, misal batuk dan bersin

b) Orang yang memberikan perawatan kepada individu dengan gejala pernapasan

c) Petugas kesehatan, ketika memasuki ruangan dengan pasien

Berikut beberapa langkah Dinkes dan bentuk upaya pemerintah Indonesia dalam menangani serta menghadapi Covid-19 :

1. Pemerintah Indonesia, melalui Kementerian Kesehatan, telah melakukan berbagai langkah pencegahan masuknya COVID-19 ke wilayah Indonesia, yaitu:

a) Menerbitkan surat edaran kepada seluruh Dinas Kesehatan Provinsi dan Kab/Kota, Rumah

Sakit Rujukan, Kantor Kesehatan Pelabuhan (KKP), dan Balai Teknik Kesehatan Lingkungan (BTKL), untuk meningkatkan kewaspadaan dan kesiapsiagaan dalam menghadapi kemungkinan masuknya penyakit ini.

b) Menempatkan 135 thermal scanner di seluruh bandar udara di Indonesia terutama yang mempunyai penerbangan langsung dari Republik Rakyat Tiongkok (RRT)

c) Memberikan health alert card dan Komunikasi, Informasi, dan Edukasi (KIE) pada penumpang.

d) Menunjuk sedikitnya 100 Rumah Sakit Rujukan yang sebelumnya dipakai pada kasus flu burung dan menyiapkan 21 kapsul evakuasi (meja dorong isolasi pasien) sebagai langkah pencegahan.

2. Kementerian Kesehatan membuka kontak layanan yang dapat diakses masyarakat untuk mencari informasi perihal virus corona.

Nomor layanan informasi yang dapat dihubungi adalah 0215210411 dan +6281212123119 .

3. Pada 2 Februari 2020, Pemerintah Indonesia mengumumkan:

a) Penundaan seluruh penerbangan dari dan ke RRT yang berlaku mulai 5 Februari 2020 pukul 00.00 WIB.

b) Pelarangan seluruh orang masuk dan transit ke Indonesia apabila selama 14 hari terakhir berada di RRT.

c) Pencabutan sementara bebas visa dan visa on arrival untuk warga negara RRT.

d) Penghentian sementara impor live animal dari RRT.

4. Sebagai bentuk perlindungan, Pemri telah memulangkan WNI dari Provinsi Hubei, RRT, pada 2 Februari 2020. Kepada para WNI tersebut telah diterapkan langkah-langkah sebagai berikut:

a) Memastikan ketersediaan dan akses terhadap logistic di Wuhan (sebelum dilakukan evakuasi): karena adanya kebijakan karantina dari Pemerintah RRT, KBRI Beijing telah mengirimkan bantuan dana kepada WNI yang sebagian besar merupakan mahasiswa untuk keperluan membeli makanan dan logistic di Wuhan.

b) Mengirimkan bantuan logistic dari Indonesia: BNPB melalui Kementerian Luar Negeri dan KBRI Beijing telah mengirimkan 10.000 masker N-95 untuk WNI di RRT.

c) Melakukan penjemputan sukarela: 237 WNI dan 1 WNA yang berada di Provinsi Hubei pada tanggal $1-2$ Februari 2020.

d) Sejak tanggal 2 Februari 2020, seluruh WNI bersama 5 tim aju dari KBRI Beijing serta 42 anggota tim evakuasi menjalani observasi kesehatan selama 14 hari (masa inkubasi virus) di Pangkalan Udara TNI AU Raden Sadjad di Pulau Natuna.

e) Pada 15 Februari 2020, seluruh WNI beserta tim evakuasi telah menyelesaikan masa karantina observasi kesehatan dan dinyatakan sehat, bebas dari virus corona.

Dari tujuh protokol dan langkah upaya yang telah disampaikan oleh pemerintah dan Dinkes diharapkan dapat diterapkan oleh masyarakat secara baik dan benar. Dengan tetap tenang dan patuhi segala aturan yang telah di tetapkan oleh pemerintah serta tetap menjaga kebersihan dan menerapkan hidup sehat, jangan lupa untuk cuci tangan, menghindari menyentuh area muka serta berjemur di bawah sinar matahari agar imun di dalam tubuh dapat meningkat. Jika imun tubuh meningkat maka resiko tertular virus sedikit. 
Serta, partisipasi dan kesadaran masyarakat bersama dengan pemerintah dalam menangani penyebaran Covid-19 sangat diperlukan yakni dengan mengikuti aturan yang ditetapkan pemerintah pusat dan daerah seperti menjaga jarak, rajin cuci tangan dan menerapkan pola hidup sehat. Peran masyarakat sangat penting sekali mulai dari tingkat kelurahan, RT/RW untuk memantau warganya apakah berpergian keluar kota, mencegah agar tidak melakukan kumpul - kumpul dan mendata warganya yang termasuk ODP atau PDP, Selain dengan sosialisasi tim lapangan juga melakukan penyemprotan area pemukiman dan rumah warga, warung, pertokoan dan fasilitas umum. Ini upaya pemerintah bagaimana penyebaran virus bisa dihentikan. Untuk mengatasi virus corona ini pemerintah tidak bisa bekerja hanya sendirian tetapi memerlukan partisipasi dari semua komponen masyarakat, termasuk tokoh agama, tokoh masyarakat dan lembaga masyarakat lainnya untuk membantu pemerintah menyampaikan ke masyarakat terkait dengan pencegahan covid-19 supaya penyebaran covid-19 tidak semakin meluas.

\section{KESIMPULAN}

Sosialisasi secara sederhana dapat dipahami sebagai proses internalisasi nilai dan orma sosial ke dalam individu. Melalui sosialisasi, seseorang secara berangsur-mengenal persyaratan-persyaratan, tuntutan- tuntutan dan kebijakan-kebijakan yang telah di sepakati secara bersama. Dalam mensosialisasikan mengenai covid-19 pemerintah mempunyai strategi untuk masyarakat dengan memberi penjelasan mengenai pandemic yang mewabah yaitu dengan cara memberikan penjelasan menggunkan bahasa daerah masing-masing yang diharapkan masyarakat bisa memahami dengan benar apa yang telah disampaikan oleh pemerintah Pemerintah telah merilis situs covid19.go.id untuk memberikan edukasi kepada masyarakat terkait virus Corona terbaru. Untuk pencegah penularan, cara yang sebaiknya dilakukan adalah dengan mengetahui risiko dan menghindarinya termasuk dengan menjaga kebersihan. Namun, pemerintah juga menyarankan bagi masyarakat untuk melakukan social distancing atau mengurangi kontak langsung dengan orang lain. Di sisi lain, masyarakat diharapkan untuk dapat membedakan informasi yang salah atau berita hoaks yang beredar. Pasalnya, kemudahan melakukan komunikasi yang didukung dengan perangkat digital justru sering disalahgunakan dengan banyaknya penyebaran informasi yang salah. Jika memenuhi kriteria suspek virus corona (COVID-19), Anda akan dirujuk ke salah satu rumah sakit rujukan yang siap menanganani COVID-19. Namun, jika tidak memenuhi kriteria suspek, Anda akan dirawat inap atau rawat jalan tergantung diagnosa dan keputusan dokter. Partisipasi dan kesadaran masyarakat bersama dengan pemerintah menangani penyebaran Covid-19 sangat diperlukan yakni dengan mengikuti aturan yang ditetapkan pemerintah pusat dan daerah seperti menjaga jarak, rajin cuci tangan dan menerapkan pola hidup sehat.

\section{DAFTAR PUSTAKA}

Adetia Reza Ariska, Apri Diansyah, Erlina Lestari, Ratna M, Massayu Aliza. 2014. "Resume Sosialisasi Politik Fakultas Ilmu Sosial Dan Ilmu Politik Universitas Sriwijaya.” (07111002004).

Budiman, Syarif. 2017. "Analisis Hubungan Antara Hukum dan Kebijakan Publik : Studi Pembentukan UU No . 14 tahun 2008 ( Analysis of Relation Between Law and Public Policy: Abstrak." Jurnal Ilmiah Kebijakan Hukum 2008(14): 109-19.

D. Herdiana. 2018. "Sosialisasi Kebijakan Publik: Pengertian Dan Konsep Dasar." Jurnal Ilmiah Wawasan Insan Akademik (November).

Fatkhuri, Fatkhuri. 2018. "Korupsi Dalam Birokrasi Dan Strategi Pencegahannya." Jurnal Ilmiah Manajemen Publik dan Kebijakan Sosial 1(2).

Hendri. 2018. "Implementasi Sosialisasi Peraturan Pemerintah No. 23 Tahun 2018 Bagi Pelaku Usaha Mikro, Kecil Dan Menengah (UMKM).”Jurnal Vokasi Indonesia 6(2): 53-58.

Kementrian Dalam Negri. 2013. "Pedoman Umum Menghadapi Pandemi Covid 19." Journal of Chemical Information and Modeling 53(9): 1689-99.

Sumaryana, Asep. 2005. "Birokrasi dan Pelayanan Publik Asep Sumaryana Staf Pengajar Administrasi Negara FISIP Unpad Dan Kepala Bidang Pengkajian LP3AN.” Jurnal Sosiohumaniora 7/No. 2: 133-42. 
Yunus, Nur Rohim, and Annissa Rezki. 2020. "Kebijakan Pemberlakuan Lock Down Sebagai Antisipasi Penyebaran Corona Virus Covid-19.” Salam: Jurnal Sosial dan Budaya Syar-i 7(3).

\section{Artikel dan Internet}

https://www.popmama.com/life/health/ninda/dinkes-panduan-isolasi-diri-sendiri-dalam-penangananvirus-corona/full

https://kemlu.go.id/hanoi/id/news/5105/langkah-dan-upaya-pemerintah-indonesia-dalam-menanganidan-menghadapi-covid-19 